\title{
東京都心部の内水氾濫と 大規模地下空間浸水の危険度に関わる数値解析 \\ NUMERICAL SIMULATION OF INUNDATION IN URBAN AREA OF TOKYO AND UNDERGROUND SPACE
}

\author{
関根正人 ${ }^{1}$ ・古木 雄 $^{2} \cdot$ 関根貴広 $^{2}$ \\ Masato SEKINE ${ }^{1}$, Yu FURUKI ${ }^{2}$ and Takahiro SEKINE ${ }^{2}$ \\ ${ }^{1}$ 正会員 工博 早稲田大学理工学術院教授（† 169-8555 東京都新宿区大久保 3-4-1) \\ 2 学生会員 早稲田大学大学院創造理工学研究科（同上）
}

\begin{abstract}
Recently extremely strong rain came to attack the urban areas of Tokyo. As a result, urban inundation came to be frequent. Because there are several underground spaces including subway stations in this highly urbanized area in Tokyo, appropriate measures must be taken beforehand. Numerical simulation is effective to reduce damage of the inundation. In this study, we applied numerical prediction technique developed by the first author to the Tokyo downtown area. Based on the result, the inundation risk of the actual large-scale underground was made clear.
\end{abstract}

Key Words : urban inundation, underground inundation, torrential rain, numerical simulation.

\section{1. 序論}

近年，我が国では各地で記録的な豪雨に見舞われてい る.このうち，2014 年 8 月に主として西日本で甚大な 被害をもたらした豪雨は「平成 26 年 8 月豪雨」と命名 され，特に広島市で大規模な土砂災害が発生したことは 記憶に新しいところである．豪雨による被害は東京都心 部でも確認されており，たとえば2013 年 7 月 23 日に 世田谷区や目黒区で「記録的短時間大雨警報」が出され た.この時には，各地で床上・床下浸水被害となったほ か公共交通機関にも大きな影響が生じた．東京都心部の ような「高度に都市化されたエリア」では，下水道と都 市河川によって雨水を排除するシステムができあがって いる．しかし，設計降雨強度である $50 \mathrm{~mm} / \mathrm{h}$ を超えるよ うな豪雨が都市でも頻発するようになっている現状を考 えると，これまでに整備されてきたハードウエアだけで 十分に安全と言うことはできず，さらに高強度の豪雨に 対する備えを進めていくことが求められている.

東京都心部がこれまでに経験したことのない豪雨に見 舞われた場合に，最も大きな被害が懸念されるのは地下 空間である．都心部の地下には縦横に地下鉄が延び，路 線間の乗り換えを考えて，地下通路によって駅同士が相 互に結ばれている. また, 駐車場を併設した地下商業施 設など多くの大規模地下空間が開発されている.たとえ
ば，東京駅や新宿駅・渋谷駅などのターミナル駅にはこ のような地下空間が存在する. もしもこれらの駅の周辺 エリアの地上部分に深刻な浸水が発生すると，その氾濫 水は連絡口を通じて地下空間に流れ込み，地下浸水が引 き起こされる恐れがある．新宿や淽谷の地下街ではこれ までにも浸水被害を受けたことがある.今後さらなる地 下浸水対策が必要である.

著者らは，豪雨時に東京都心部において発生する浸水 を数值的に予測し, 浸水危険度を評価するための研究を 続けている ${ }^{1), 2)}$. この都市浸水を予測する上で核となる 現象は，道路上・下水道内ならびに都市河川における水 の流れであり，これらを相互に結ぶ「雨水ます」などを 通じての水のやりとりである。このような予測計算を可 能にする手法として，第一著者により開発された「街路 ネットワーク浸水・氾濫解析手法」がある ${ }^{1)}$. この手法 では，道路により囲まれたエリアを「街区」と呼ぶこと にし, 街区の大半を占める建物に降った雨水については, 下水道に直接流れ込むように計算される。これは住宅な らびにビル群がそのように設計されているためである. 一方，建物の間にわずかに残されたスペースに降った雨 については，街区内をさらに分割してその流れを解析す ることにより，道路との水の流出入を可能な限り現実に 即して計算している ${ }^{2)}$ 。この手法の妥当性・再現性につ いては，現時点で可能な限りの検証を行ってきた ${ }^{1)}$. 例 


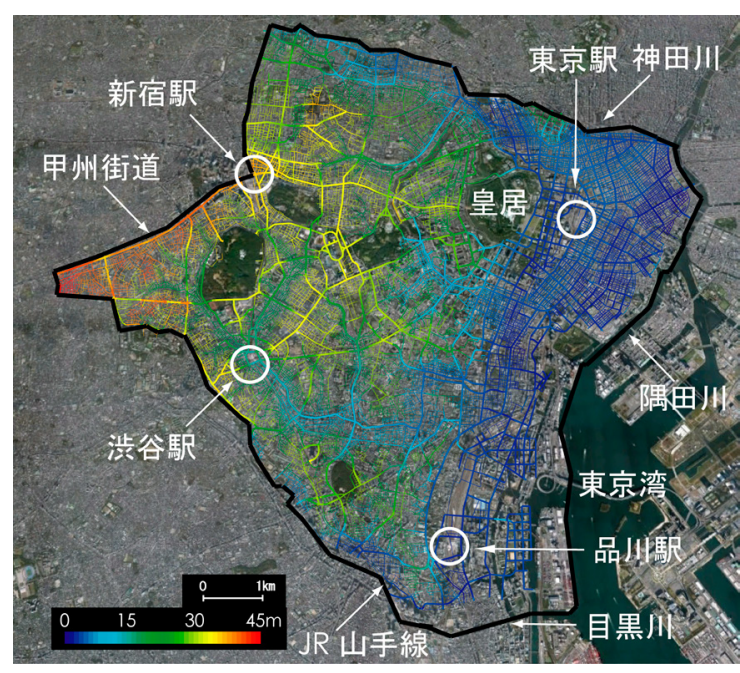

図 -1 対象区域内の道路標高のコンタ一図 背景は Google Earth の画像を引用したものである.

えば, 2005 年 9 月に発生した杉並豪雨による妙正寺川 流域の浸水・汇濫被害の再現計算や， 2008 年に豊島区 雑司が谷で発生した下水道水難事故時の雨水の集中状況 の再現計算を行い，これらの計算結果と観測結果とを比 較した. これにより, 手法の妥当性が確認されたと考え る.

本研究では，JR 山手線により囲まれた東京都心部のう ち神田川の南側に位置する区域を対象に，その浸水危険 度を評価することを目指した。この区域には，主要なも のだけでも 700 以上の連絡口が存在し，これを通じて 道路面と地下空間とがつながっている. このため, 豪雨 による地上の浸水に加えて, 各連絡口からの汇濫水の流 入の可能性についてもあわせて探ることにした. さらに, 対象区域内に位置する地下空間のうち我が国屈指の大規 模地下空間を対象にして，その地下浸水に関わる予測計 算もあわせて行い，その地下浸水の危険度の評価も行っ た。 なお，この地下浸水解析には，第一著者により開発 された手法を適用している ${ }^{3)}$.

本研究に関連する研究としては, 近年継続的に進めら れている大阪梅田を対象とした研究 ${ }^{4)}$ などがある.

\section{2. 解析の概要}

\section{(1) 対象区域とその概要}

本研究では図 -1 で示される東京都心部に位置する区 域を検討の対象とした。 この区域の境界は次のようにと られている，北側境界を神田川，東側境界を隅田川なら びにその下流に位置する東京湾沿岸とした．また，南側 ならびに西側境界は，主として目黒川あるいはJR 山手 線上にそれぞれとられている. その総面積は $64.4 \mathrm{~km}^{2}$ である. 図 -1 に描かれているのはこの区域内に位置す る道路面の標高コンター図である。この図から，西側に 位置する内陸部から東側の東京湾に向かって標高が低く

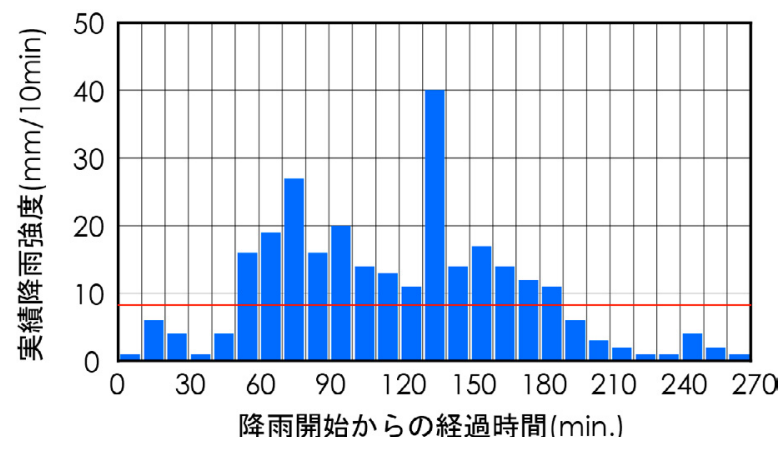

図 -2 対象降雨のハイエトグラフ

(2005 年 9 月に杉並区下井草で観測された降雨データ)

なっている様子が見てとれる．また，道路上の雨水が集 まりや寸い谷地形が各所に現れている. その典型のひと つが啮谷駅周辺であり，駅に向かって下るようにいくっ もの坂が延びている.このため, 道路上に降り注いだ雨 水が速やかに駅周辺に集まり, 結果として規模の大きな 浸水となる恐れがある.

対象区域の特徵は以下の通りである. 寸なわち，この 区域には国会議事堂や政府機関，銀行を含めたわが国の 主要な企業の本社ビルなどが集中して存在する.また, 東京の主要な鉄道路線や東京・新宿・渋谷・品川などの ターミナル駅がある. さらに，これらの駅の地下には大 規模地下空間が開発されているほか, 合計 13 路線の地 下鉄がこの区域の地下を縦横に延びており，百を超える 地下鉄駅が存在する. 下水道の排水能力を超える豪雨に 襲われたとき，最も浸水を懸念しなければならないのは 谷地形の凹部に当たるエリアであり，その地下に広がる 大規模地下空間である. 地上で深刻な浸水が生じると, その水が連絡口・連絡階段を通じて地下空間に流れ込み, 地下浸水にまで到る可能性がある。これを防ぐために止 水板を設置するなどの対策が進んでいるが，ひとつの地 下空間につながる連絡口の数は数十にも及ぶ. このよう な地下空間の場合には，道路から汇濫水が流孔込む可能 性のある連絡口を特定するとともに，その地点が具体的 にどの程度の浸水深となるのかを明らかにすることが重 要である.このような点についての科学的根拠が示され ると，実効性の高い対策をとることができる.

\section{(2) 対象降雨}

本研究では，2005 年 9 月に杉並区下井草で観測さ れた豪雨（これを「2005 年杉並豪雨」と呼ぶ）を対 象とし，この雨が対象区域内に一様に降るとした想 定で数值解析を行った。 なお，この雨は東京都 23 区でこれまでに観測されている豪雨の中でも最大級 のものである. 図-2 はその降雨ハイエトグラフを示す. 図の縦軸は 10 分間雨量 $(\mathrm{mm} / 10 \mathrm{~min})$ を, 横軸は降雨開 始からの経過時間をそれぞれ表す．図中の赤線は下水道 の設計降雨強度である時間雨量 $50 \mathrm{~mm}$ を表す。この雨 

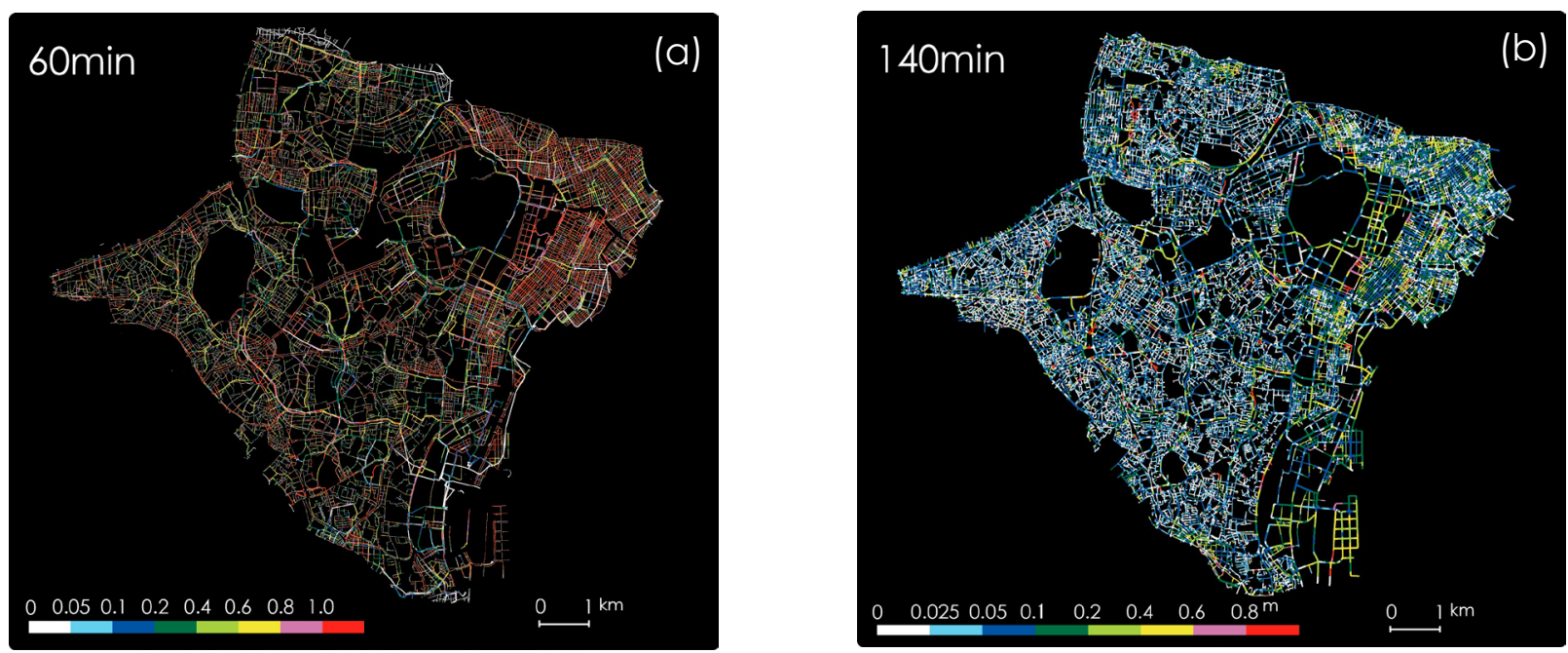

図 -3 豪雨に伴い地上で発生する浸水状況

(a) 降雨開始 60 分後の下水管内の満管率コンター図, (b) 降雨開始 140 分後の道路上の浸水深コンター図

の特徴は，2 時間以上にわたって $50 \mathrm{~mm} / \mathrm{h}$ を超える強度 の雨が降り続いたことと, 10 分という単位ながら極め て強い雨が繰り返し発生したことにある. なお，対象区 域内に一様な雨を与えて検討したのは，区域内の各地点 で想定される浸水深の大小 (これを「浸水危険度」と表 現することにする）を相対的に比較するためである.

\section{（3）浸水予測の概要}

数值解析は, 第一著者による「街路ネットワーク浸水・

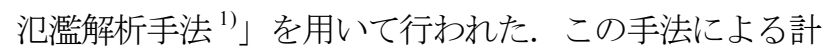
算にあたっては，道路ならびに街区・下水道・都市河川 に関わる詳細なデータがすべて入力され，それぞれの水 の流れが忠実に計算される. 本研究で対象とするような 「高度に都市化された区域」における雨水の主な流れを 整理すると次のようにまとめることができる，まず，地 上に降った雨は道路上を流れ下り，標高の低い地点に向 かって流れる.ただし, 汇濫水の一部は，その途上で道 路側方にある「雨水ます」を通じて下水道内に取り込ま れることになる. これに伴い，下水道内の流れは，その 経路に沿って地上からの雨水の流入を受け，その流量を 大きくしながらのものとなる. 下水道は合流・分流を繰 り返す複雑なネットワークになっており, 最終的には「雨 水吐」を経由して都市河川または東京湾に流れ出るか, またはポンプ場あるいは水再生センターに運ばれた後に 河川または海に排出される. 本研究で対象とする区域に は，神田川とその支川である日本橋川・亀島川，さらに は渋谷川・古川が流れている. ポンプ場は合計で 13 箇 所存在するほか, 南東端に芝浦水再生センターがある.

本解析では，路地までを含めた実在するすべての道 路，ならびに枝線に到るまでのすべての下水道を，一切 省略することなく考慮した. これにより, 現状の都市イ ンフラのすべての機能を忠実に反映させた解析が可能で ある. また, 水理学の基礎原理である運動方程式と連続
式に基づいて水の流れを解いており，特別な仮定の導入 や簡略化は行っていない.

地上部で発生する浸水についての検討に加えて, 本研 究では，東京駅の西側に広がる大規模地下空間の浸水リ スクについても検討した. 本研究では，大手町・丸の内・ 日比谷・有楽町・銀座など合計 10 を超える地下鉄駅を 相互に結ぶように延びる地下通路に注目し, 丸の内地下 空間と呼ぶ。 また，この対象区域内には 60 以上の地下 鉄駅が存在しており，その中には前論文 ${ }^{4)}$ において地下 浸水解析を行い，その浸水リスクについて論じた溜池山 王駅も含まれる. 本研究では, (1)このふたつの地下空 間へとつながる連絡口を通じた汇濫水の地下への流入が 完全に遮断できるとした場合 (「シナリオ -1」と呼ぶ) と, (2) 連絡口に止水板が設置される前に浸水が発生してし まうとした場合（「シナリオ-2」と呼ぶ）のふたつにつ いて数值予測計算を行った. 前者は, 事前に十分な高さ の止水板が準備されているとし，これらが遅れることな く設置された場合を表している. 一方, 後者は現状の地 下空間にとっては最も深刻な事態となるシナリオと言え る. なお，ここでは，あくまでも丸の内地下空間と溜池 山王駅につながる合計 150 の連絡口に限って止水板の 有無を考慮した計算となっている. これらの連絡口から の汇濫水の流入は，道路上の水位が各連絡口の高さを越 えた場合に生じ，その量は段落ち式により評価した。な お，地上ならびに地下空間で生じる浸水は一連の現象と して生じることから,ここでは両者の同時解析を行った. なお， 2014 年 8 月時点で調査した結果によると，東 京地下鉄 (株) による止水板の設置が先行して進められ たのに対して，民間ビルから地下通路へとつながるその 他の連絡口ではその設置が未着手である場合も少なくな い. ただし，設置工事が完了しているとしても，止水 板を豪雨時に遅帯なく設置できるか否かは定かでなく, 万一対応に遅れが生じると浸水に到ることもあり得る. 


\section{3. 対象区域内の浸水リスクの評価}

この章では，2005 年杉並豪雨をひとつの基準降雨 とし，この降雨時に対象区域内のどこに浸水のリスク が潜んでいるかを検討した結果について説明する.

図 -3には，「シナリオ -2」の計算結果を例に，この降 雨時に発生する浸水のプロセスに関する特徽的な結果の み示す. 図-3 (a) は, 下水道内の流れが満管状態となる 地点がある程度現れてくる時刻における満管率コンター 図を表している.ここに，満管率とは各地点を中心とす る control volume 内の下水道の容積に対する実際に存在 する水の体積の比率のことを指す ${ }^{3)}$. 対象とした降雨の 場合には，降雨開始から 60 分後には下水道内のほとん どの区間でこのような状態となることがわかった. また， 図 -3 (b) は，地上の浸水状況が最も深刻になると判断さ れた時刻における道路上浸水深のコンター図である。本 解析の場合, この時刻は降雨開始から 140 分後に現れる. 図 -2 の降雨ハイエトグラフを見ると, 前者は降雨が下 水道の設計強度を超えてから 10 分後に当たり，後者は 降雨が二つ目のピークをとった直後に相当する. 参考ま でに，この結果を「シナリオ -1」の場合と比較すると， 前述の地下空間につながる連絡口付近の浸水深が $0.2 \mathrm{~m}$ 程度小さくなる点が現れることを除けば，本質的な違い は認められない.これは，氾濫水が地下空間に流入した 体積分だけ, 地上の浸水深が小さくなったことを意味し, その差はコンター困の凡例にして一階調分程度であるこ とを意味する．なお，図-3 (b) に関連して，各地点に おける浸水深の最大值を求めて図化したところ，その結 果は図-3 (b) と完全に一致することがわかった. そこで, 図-3 (b) は，既存のハザードマップに相当する「浸水 危険度情報」と位置づけることもできる.

図 -4には，降雨開始 140 分後の道路上を流れる汇濫 水の流速の絶対值のコンター図を示した. これは「シナ リオ -2」の結果である. この図から流向を判読するこ とはできないが，どの地点でどの程度の流れが生じたか はわかる．図は浸水状況が最も深刻となる時刻における ものであり，地点によっては $0.6 \mathrm{~m} / \mathrm{s}$ 以上の流れが発生 していたことがわかる. この結果について考察を加えた ところ, 汇濫水の流速が大きくなるのは，比較的勾配の 大きな下り坂となっている道路上であることが確認され た. 図-1 よりわかるように，対象区域は内陸にあたる 西側から東京湾沿岸部の東側（すなわち図の右側）に向 かって標高が低くなっていく傾向にあり, 図の左右中央 部付近の山の手から下町に向からエリアにこのような急 勾配の道路が存在する. そして，このような道路を下り きった先の地点付近では，下水道の敷設状況に応じて道 路上浸水深が大きくなるところが現れている.このよう な地点で浸水深が短時間で増大してしまうのは，道路上 の流速がこのように大きくなり，汇濫水の集中が速やか に進むためである. また，このような地点に地下につな

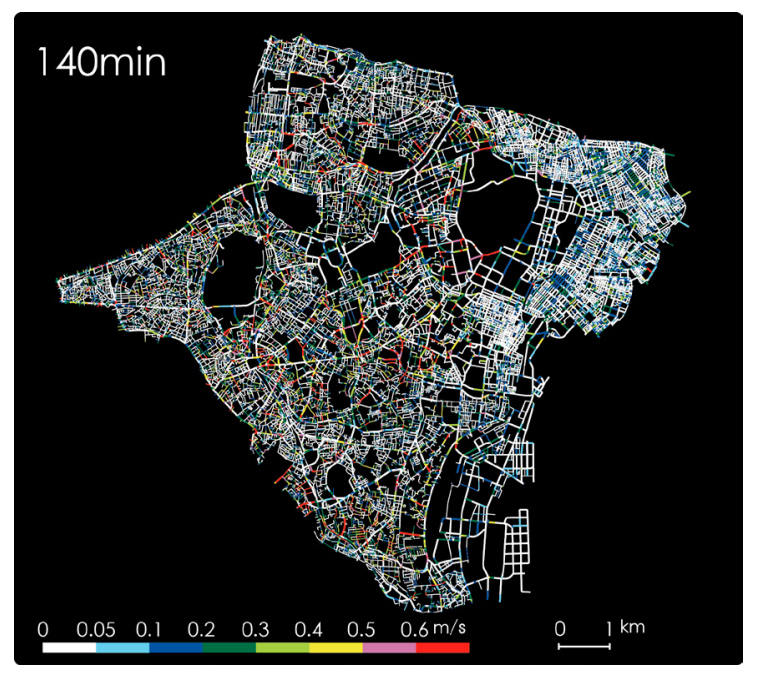

図 -4 道路上の流速コンター図（降雨開始 140 分後）

がる連絡口があり，かつ入口が下り坂に面して開いてい る場合には，流速の大きな流れが接近し流れ込むことに なる. 止水板などにより地下空間への水の流入を阻止す る上ではこの点にも注意を要する.

\section{4. 対象区域内に存在する地下空間の浸水リスク}

\section{（1）地下浸水の危険度}

対象区域内の道路（主として歩道上）には，地下空間 につながる連絡口が合計で 1,000 程度は存在する. 本研 究では前述の 2005 年杉並豪雨時に, その各々から汇濫 水が流入する可能性があるか否かを検討した. ここで は，「シナリオ -1」の予測計算の結果に基づいて，該当 地点での道路上浸水深の最大值が各連絡口の高さを超え るか否かによって，その判定を行うことにした，その結 果によれば, (1) 止水板なしの条件下では, 検討対象と した約 750 の主要な連絡口のうち 222 箇所から地下空 間に向かって水が流入すること，(2)このうち，2014 年 8 月時点で止水板が準備できている連絡口二箇所を除け ば，十分な高さの止水板が用意されており，遅帯なくそ の設置が完了しさえすれば汇濫水の浸入を防ぐことがで きること，(3) 止水板の設置が必要であるにもかかわら ず，それがなされていない連絡口が依然として存在する こと, などが明らかになった. 浸水の危険性を認識して, 管理者は事前に対策を講じておくとともに，いざという 時に速やかに止水板を設置できる体制を整えておくこと が必要である。

\section{（2）大規模地下空間の浸水プロセス}

ここでは，丸の内地下空間を例に，大規模地下空間の 浸水プロセスについて説明する.この地下空間の場合, 地上とつながる連絡口の数は主要なものだけでも 146 箇所ほど存在する.「シナリオ -2」の解析により, それ ぞれの連絡口上端での越流水深ならびに流入流量の時間 

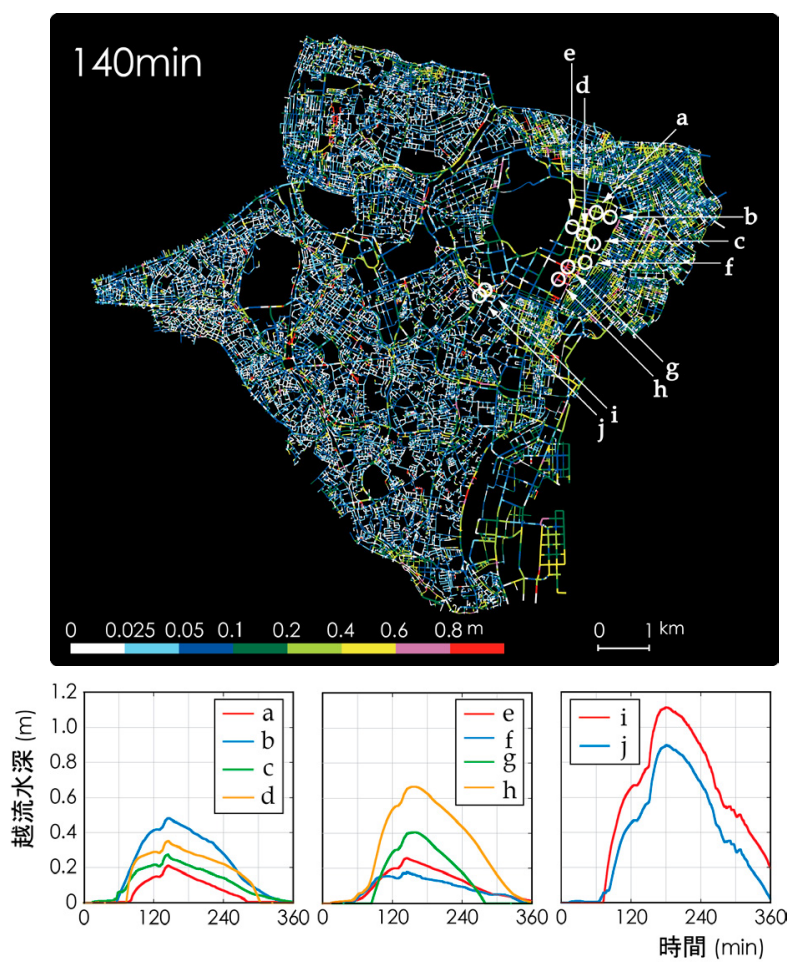

図 -5 地下空間へとつながる連絡口の位置とその地点での 越流水深のハイドログラフ

変化に関する計算結果が得られている. このうち, 比較 的大きな流入が予想される十箇所の連絡口の越流水深に 関わるハイドログラフを示したものが図 -5 である.こ の図の背後に示されているのは「シナリオ $-1 」 の$ 計算 結果であり，これは図-3(b) に対応するものである.こ の図より，用意されている止水板の設置が間に合わない ような事態になると, 複数の連絡口を経由してこの地下 空間に水が流れ込むことになる．ただし，この連絡口の ほとんどにはすでに止水板が設置できるような準備がで きていることを付記する.

次に，図-5のような流入が発生することに伴って進 行する地下空間の浸水プロセスについて説明する. 図 -6には, 記載の時刻における地下空間内の浸水深コン ター図が描かれている。この地下空間は明確な層構造に はなっておらず, 高さの異なるフロアが内部階段を通じ て複雑につながっている. 図一6はこれをあえて平面図 として描いたのものであり，高さは異なるものの平面的 に重なり合う区域については，下方に位置するものを矢 印の先に抜き出して示寸ことにした．たとえば，地下鉄 駅のコンコース部分の真下に存在するプラットホームに ついては，白色の矢印の先に抜き出して描いてある。 な お，この解析の場合には，地下鉄の軌道ならびにトンネ ル部分をあえて考慮することなく，プラットホームに到 達した水をそこに留めることにした. 最下層にあたるプ ラットホーム上の水深が $3 \mathrm{~m}$ にもなっているところがあ るのはそのためである. 数字自体に大きな意味はないも のの，そのエリアでは極めて危険な状態に到る可能性が
あることは理解できよう. トンネルを通じての汇濫水の 輸送については別途検討を進めているところであり，こ れについては改めて次の機会に説明する.

この図からわかるように，地下通路が連続するように 延びる大規模地下空間の場合には, 地上とつながる連絡 階段や各フロアを結ぶ内部階段が多く, これらが複雑に 接続されているため, 極めて複雑な浸水のプロセスとな る.

地下空間の浸水被害軽減対策を検討寸る際に重要なこ とは, (1) 地上の汇濫水の流入を防ぐ止水板などのハー ドウエアを事前に準備しておくこと，(2) 万一，水の流 入を許してしまったときを想定して，いざという時の避 難誘導について考えておくこと，の二点であると考え る. 現状では (2)の検討まで行われている地下空間は少 ないようである.これを行うためには, 地下浸水が発生 することをも想定し, いざという時の水の流入経路なら びに浸水域の拡大過程を知ることが必要となる. 地上の 浸水予測と同時に地下空間の浸水予測計算を行うことに より, 本論文で説明したような情報を得ることができる. さらに言えば，このような数值予測を踏まえ，これと連 動して利用者の避難行動を解析可能なシミュレーション 手法 ${ }^{3)}$ も提案されている. 地下空間の浸水被害を軽減す るために，これらの計算技術が有効に活用されていくこ とが望ましい.

\section{5. 結論}

本研究では，東京都心部に位置する芝浦下水道処理区 にあたる区域を検討の対象とし，2005 年杉並豪雨を想 定した都市浸水予測を行った. また, これと連動して, この区域内に存在する大規模地下空間の浸水予測もあわ せて行った. 本研究により明らかになった知見は以下の 通りである.

(1) 都心部に杉並豪雨と同等の雨が襲った場合に, 雨水 がこの区域内の下水道に速やかに集中寸る状況や，そ の結果として地上の浸水深が $1 \mathrm{~m}$ を超える地点が現れ ることなどが明らかになった。

(2) 道路上を流れる汇濫水の流速についても新たに結果 を取りまとめ考察を加えている. 対象区域内には勾配 の急な道路が多く存在しており, このような道路上で 相対的に大きな流速となり, 地点によっては $0.6 \mathrm{~m} / \mathrm{s}$ を超えるという計算結果が得られた。

(3) 本研究で対象とした区域に存在する地下空間への連 絡口のうち主要な 700 を超えるものを対象に止水板 の準備状況なじを確認し, 杉並豪雨に相当する豪雨時 にその各々から汇濫水が流入する可能性を検討した. その結果として，止水板の設置が間に合わない（ある いは存在しない）場合には，200を超える連絡口から 水が流入し，地下浸水に到ることがわかった．また， 止水板が事前に設置できたとしてもその高さが不足 

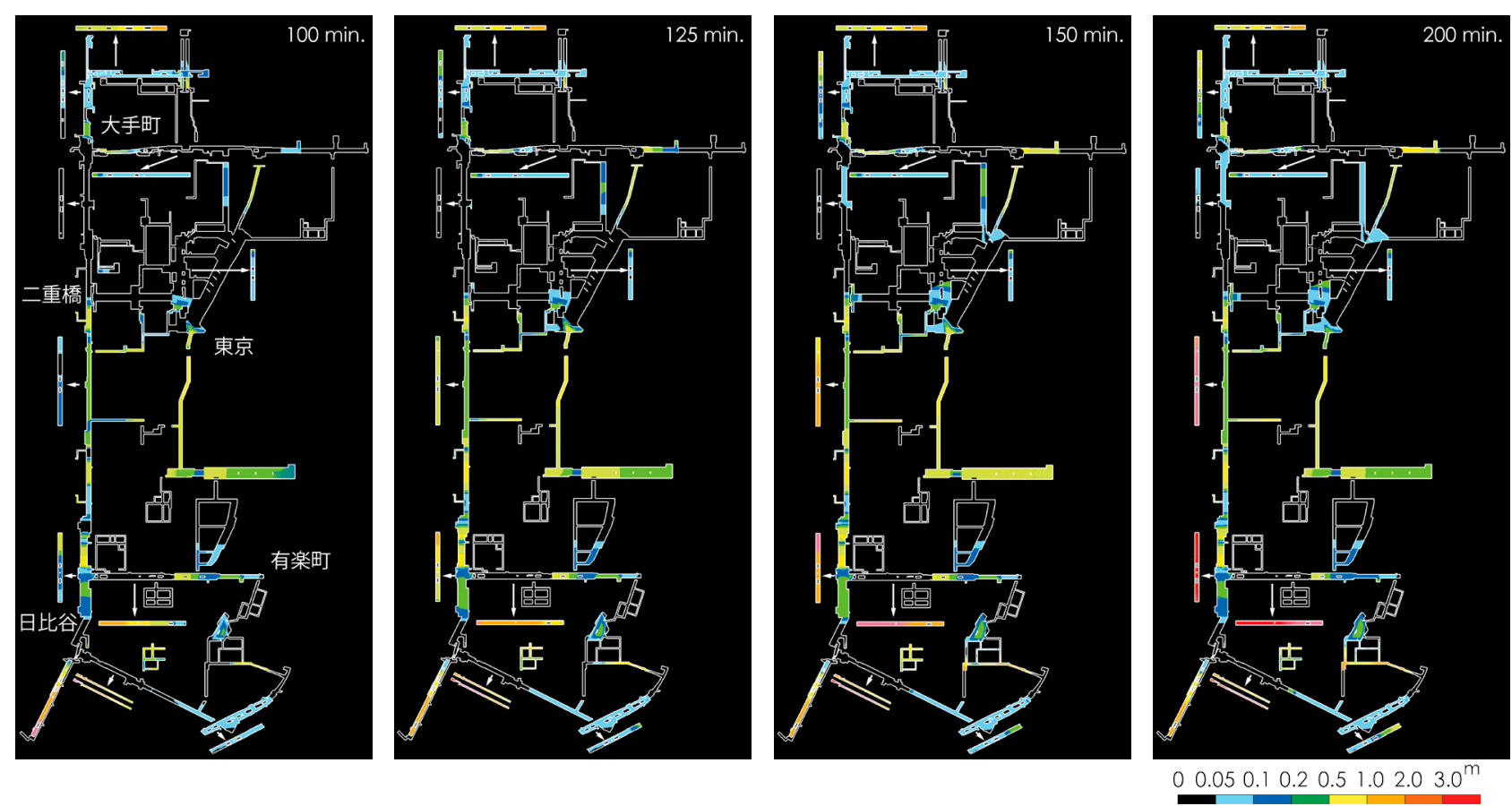

図 -6 大規模地下空間における浸水深コンター図の時間変化（白線に囲まれたエリアが地下空間を表す）

する箇所があることも明らかになった。

(4) 対象区域内に存在する丸の内の大規模地下空間を対 象に, 地上ならびに地下空間の同時浸水解析を行った. 結果として, 万一, 用意されている止水板の設置に遅 れが出ると, 複数の連絡口から同時に水が入り込む可 能性が高いことが理解された. また，そのときの浸水 域の拡大プロセスはたいいん複雑なものとなる。これ は，この地下空間が地下通路を中心とする複雑な構造 を有するものであり，地上とつながる連絡口・連絡階 段が主要なものだけでも 146 箇所ほどあるほか，多 数の内部階段によって各フロアが複雑に結ばれてい るためである.いざというときに利用者が安全に避難 できるようにするには，本論文で説明した浸水予測の 結果などを踏まえて, 事前の準備と適切な誘導を行う ことが不可欠である.

今後は，著者による予測手法が実務においても有効に 活用され，浸水被害軽減に向けて役立てられるようにす るため, さらに検討を続けていく予定である. そのひと つ，リアルタイム浸水予報技術の開発があり，たとえ ば止水板を設置するタイミングを的確に判断できるよう な情報を提供していきたいと考える.

謝辞: 本研究は, 国土交通省水管理 - 国土保全局下水 道部による「ICT 技術を活用した地下街都市ゲリラ豪 雨対策システム検討会」での議論のために行った数值解 析を，その後さらに精緻にやり直した結果をまとめたも
のである. 同省の加藤裕之氏 ( 当時, 下水道事業調整 官）には日頃からの意見交換に加えて，地下空間に関わ るデータの提供に当たって特段のご配慮をいただきまし た.ここに記して謝意を表します。東京地下鉄株式会社 など関連する地下空間の管理会社には具体的なデータに 関してご協力をいただきました．東京地下鉄株式会社の 武藤義彦氏・小西真治氏をはじめとした皆様に対して感 謝申し上げます. 最後に, 学生として本研究に携わった 三浦綾華君, 酒井俊一君, 竹順哉君にも感謝します。

\section{参考文献}

1) 関根正人 : 住宅密集地域を抱える東京都心部を対象とした 集中豪雨による内水汇濫に関する数值解析，土木学会論文 集 B1 (水工学), Vol.67, No.2, pp. 70- 85, 2011.

2) 関根正人, 和田祐樹, 佐藤裕隆: 住宅密集地を対象とした 集中豪雨時の浸水汇濫過程に関する数值解析, 土木学会論 文集 B1（水工学），Vol.68, No.4, pp. I_997- 1002, 2012.

3) 関根正人, 大野龍馬 : 集中豪雨により発生する地下空間の 浸水と利用者の避難誘導に関寸る数值解析, 土木学会論文 集 B1 (水工学), Vol.69, No.1, pp.30-43, 2013.

4) 森兼政行, 井上知美, 石垣泰輔, 尾崎 平, 戸田圭一: 地下駅を考慮した大規模地下空間での浸水特性と浸水対 応策の効果に関する検討, 土木学会論文集 B1 (水工学), Vol.68, No.4, pp. I_1003- 1008, 2012.

(2014. 9. 30 受付 ) 